\title{
PERANCANGAN APLIKASI PENJUALAN TOKO CITRA BAHARI GYPSUM BERBASIS JAVA
}

\author{
Suseno Rudiansyah ${ }^{1}$, Noni Selvia ${ }^{2}$, , Salman Alfarisi ${ }^{3}$ \\ Program Studi Teknik Informatika, Fakultas Teknik dan Ilmu Komputer, \\ Universitas Indraprasta PGRI \\ Jalan Raya Tengah No 80, Kelurahan Gedong, Pasar Rebo, Jakarta Timur \\ susenorudiansyah0503@gmail.com¹, novi.selvia@gmail.com ${ }^{2}$, salman.hotaru@gmail.com ${ }^{3}$
}

\begin{abstract}
Abstrak
Tujuan Penelitian adalah untuk membuat aplikasi penjualan pada Toko Citra Bahari Gypsum, serta mendiskripsikan hasil dan uji coba sistem aplikasi penjualan yang telah dibuat. Penelitian ini dilakukan untuk merubah proses pengolahan data dan transaksi penjualan yang sebelumnya dilakukan secara manual menjadi terkomputerisasi, yaitu dengan adanya system yang dibuat. Metode penelitian yang digunakan dalam perancangan aplikasi ini adalah metode Grounded Research, Yaitu suatu metode penelitian yang mengedepankan fakta dengan menggunakan analisa perbandingan yang bertujuan untuk mengadakan generalisasi empiris, menetapkan konsep-konsep, membuktikan teori dan mengembangkan teori dimana pengumpulan data dan analisa data berjalan pada waktu yang bersamaan. Aplikasi ini menggunakan bahasa pemprograman berbasis Java dengan database MySQL. Aplikasi penjualan yang telah dibuat digunakan untuk pendataan supplier, customer, pendataan pembelian, pendataan penjualan, pendataan barang, dan laporan kepada pemilik toko.
\end{abstract}

Kata Kunci: Perancangan, Aplikasi, Penjualan, Java, MySQL.

\begin{abstract}
The purpose of research is to create a sales application on the Citra Bahari Gypsum Store, as well as describe the results and trials of the sales application system that has been created. This research is done to change the process of processing data and sales transactions that were previously done manually to be computerized, namely with the system created. The research method used in the design of this application is the Grounded Research method, which is a research method that prioritizes facts using comparative analysis that aims to conduct empirical generalizations, establish concepts, prove theories and develop theories where data collection and data analysis run at the same time. The application uses a Java-based programming language with a MySQL database. Sales applications that have been created are used for supplier, customer, purchase data collection, sales collection, goods collection, and reports to store owners.
\end{abstract}

Keywords: Design, Application, Sales, Java, MySQL

\section{PENDAHULUAN}

Dalam dunia usaha yang bergerak dalam bidang penjualan barang sering kali ditemukan masalah, salah satunya adalah pengelolaan data stok barang yang tidak akurat dan tidak tepat. Oleh karena itu, dibutuhkan sebuah aplikasi yang bisa mengatasi masalah tersebut. Salah satu pelaku usaha yang bergerak dalam bidang penjualan barang adalah Toko Citra Bahari Gypsum, sebuah usaha kelas menengah yang menyediakan barang untuk pemasangan plafond gypsum, partisi, list profil, dan baja ringan. Di Toko Citra Bahari Gypsum proses pengelolaan data masih dilakukan secara manual, yaitu dengan menggunakan buku besar. Adanya proses pengelolaan data secara manual tersebut sering ditemukan masalah seperti pengelolaan data yang tidak akurat, data yang mudah rusak dan hilang, serta membutuhkan waktu yang relatif lebih lambat. Berdasarkan latar belakang masalah di atas peneliti tertarik untuk membuat suatu program penjualan barang sebagai bahan penelitian dengan judul "Perancangan Aplikasi Penjualan Toko Citra Bahari Gypsum Berbasis Java". Perancangan program ini didukung agar penggunaan sistem dapat lebih efektif dan efisien. Pengertian perancangan adalah proses pengembangan spesifikasi baru berdasarkan rekomendasi hasil analisa sistem.(Subhan, 2012) pendapat lain mengatakan Perancangan sistem merupakan suatu kegiatan membuat desain teknis berdasarkan kegiatan pada waktu proses analisis. (Sugianto, 2013) Kemudian pengertian Aplikasi adalah satu unit perangkat lunak yang dibuat untuk melayani kebutuhan akan beberapa aktivitas seperti sistem perniagaan, game, pelayanan masyarakat, periklanan, atau semua proses yang hampir dilakukan manusia.(Pramana, 2012) Menurut Sutabri Aplikasi adalah alat terapan yang difungsikan secara khusus dan terpadu sesuai dengan 
kemampuan yang dimilikinya. (Tata, 2012) Data Flow Diagram adalah suatu model logika data atau proses yang dibuat untuk menggambarkan darimana asal data dan kemana tujuan data yang keluar dari sistem, dimana data disimpan, proses apa yang menghasilkan data tersebut dan interaksi antara data yang tersimpan dan proses yang dikenakan pada data tersebut. (Andi, 2014) Dalam diagram konteks hanya ada satu proses, tidak boleh ada store dalam diagram konteks. (Ladjamudin, 2013) Penjualan adalah pendapatan yang berasal dari penjualan produk perusahaan, disajikan setelah dikurangi potongan penjualan dan retur penjualan.(Sulistyowati, 2010) Java merupakan salah satu dari sekian banyak bahasa pemrograman yang dapat dijalankan diberbagai sistem operasi termasuk telepon genggam. Bahasa pemrograman ini pertama kali dibuat oleh James Gosling saat masih bergabung dengan Sun Microsystems. Bahasa pemrograman ini merupakan pengembangan dari bahasa pemrograman $\mathrm{C}++$ karena banyak mengadopsi sintak $\mathrm{C}$ dan $\mathrm{C}++$. Saat ini java merupakan bahasa yang paling populer digunakan, dan secara meluas dimanfaatkan dalam pengembangan berbagai jenis perangkat lunak aplikasi ataupun aplikasi berbasis web. Netbeans merupakan sebuah aplikasi Integrated Development Environment (IDE) yang berbasiskan Java dari Sun Microsystems yang berjalan di atas swing dan banyak digunakan sekarang sebagai editor untuk berbagai bahasa pemrograman.(Nofriadi, 2015).

Tujuan Penelitian ini adalah Untuk merancang aplikasi penjualan Toko Citra Bahari Gypsum agar data tidak mudah hilang ataupun rusak, untuk memudahkan karyawan dalam proses transaksi penjualan, untuk memberikan pelayanan yang lebih cepat dan efisien kepada pemilik usaha.

Manfaat yang diharapkan akan diperoleh dari penelitian ini adalah Penelitian ini diharapkan bisa meningkatkan pelayanan yang lebih cepat, tepat, dan efisien bagi pemilik usaha, penelitian ini berguna sebagai dasar penyusunan penelitian agar memperoleh data yang akurat dan terbaru, penelitian ini bisa memberikan gambaran kepada mahasiswa untuk melakukan penelitian dalam bidang yang sama.

\section{PENELITIAN RELEVAN}

Penelitian relevan merupakan penelitian terdahulu atau sebelumnya yang relevan dengan konsep penelitian sehingga menjadi acuan atau dasar mengembangkan suatu hasil penelitian sebelumnya. Berikut peneliti mengambil sumber dari beberapa jurnal, yang pertama adalah jurnal dari Rachman, Herry dari Universitas Dian Nuswantoro, Program Studi Teknik Informatika, dengan Nomor ISSN 2303-500, pada tahun 2014 yang berjudul "Perancangan Sistem Penjualan Berbasis Aplikasi Dekstop Pada CV. Canangsari Semarang" Penelitian ini dilakukan untuk meningkatkan efisiensi waktu dalam melakukan transaksi penjualan dan untuk mempermudah dalam melakukan laporan sehingga dapat digunakan sebagai acuan laporan.(Prasetyo, 2014) Yang kedua yaitu jurnal dari Permana Adi dari Universitas Muhammadiyyah Surakarta, Program Studi Sistem Informasi, dengan Nomor 3402-645, pada tahun 2013 yang berjudul "Perancangan Sistem Aplikasi Penjualan Toko Komputer Mascom Berbasis Dekstop" Penelitian ini dilakukan untuk meningkatkan kemampuan kasir dalam pengolahan data agar lebih efisien dan mempermudah dalam melakukan inventori barang.(Adi, 2013) Kemudian peneliti juga mengambil sumber dari penelitian Chandra Maulyana, dari Universitas Indraprasta PGRI, Program Studi Teknik Informatika, dengan NPM 200943400298, pada tahun 2013 yang berjudul "Perancangan Sistem Informasi Penjualan di CV. Mekar Jaya Berbasis Java", Penelitian ini dilakukan untuk mengetahui proses transaksi penjualan yang ada di CV Mekar Jaya dan meningkatkan kemampuan karyawan dalam melakukan proses pembuatan laporan agar lebih cepat dan efisien.

\section{METODE PENELITIAN}

Metode penelitian yang dilakukan di Toko Citra Bahari Gypsum yaitu dengan mencari, memperoleh, mengumpulkan dan mencatat data yang berhubungan dengan pokok permasalahan yang terjadi di Toko Citra Bahari Gypsum dalam proses penjualannya sehingga akan didapat suatu kebenaran atas data yang diperoleh. Dalam penelitian ini, peneliti menggunakan Grounded Research, yaitu metode penelitian yang mendasarkan diri kepada fakta dan menggunakan analisa perbandingan bertujuan untuk mengadakan generalisasi empiris, menetapkan konsep-konsep, membuktikan teori dan mengembangkan teori dimana pengumpulan data dan analisa data berjalan 
pada waktu yang bersamaan. Metode pengumpulan data yang dilakukan oleh peneliti untuk mendapatkan data-data serta informasi untuk mendukung penyempurnaan hasil dari penelitian ini antara lain.

a. Teknik Observasi

Observasi merupakan kegiatan pengamatan untuk mengetahui permasalahan yang terjadi di lapangan dan survei untuk pengembangan aplikasi yang yang diusulkan, observasi ini dilakukan langsung di Toko Citra Bahari Gypsum.

b. Wawancara

Kegiatan ini dilakukan untuk memperjelas kebutuhan dalam perancangan sistem aplikasi terkait penelitian. Berupa kegiatan tanya-jawab terhadap pemilik Toko Citra Bahari Gypsum mengenai aplikasi apa yang dikehendaki untuk digunakan.

c. Studi Pustaka

Bagian ini dilakukan untuk mendapatkan data-data tertulis baik secara teoritis dan empiris yang terkait dengan topik penelitian. Selain itu studi pustaka yang dilakukan peneliti pegumpulan bahan-bahan yang berkaitan dengan judul penelitian melalui buku-buku bacaan dan situs internet, penelitian yang terkait dengan penelitian.

d. Langkah-Langkah Pengembangan Sistem

1. Analisa Kebutuhan Sistem, Bagian ini adalah bagian yang sangat penting dalam pengembangan sistem mengumpulkan informasi dan melibatkan suatu organisasi atau sistem dan mencari tahu bagaimana informasi yang ditangani saat ini. Analisa kebutuhan berguna untuk mendapatkan data-data yang digunakan sebagai masukan dari suatu sistem dan untuk memperoleh data yang berhubungan dengan judul penelitian ini.

2. Studi Kepustakaan, Studi kepustakaan bertujuan untuk mempelajari dan memahami dasar teori yang berhubungan analisa kebutuhan yang telah dilakukan. Peneliti melakukan studi kepustakaan berdasarkan referensi dan studi dari beberapa media yang berupa diktat, bukubuku maupun artikel yang ada di internet ataupun media cetak untuk mempelajari dan terselesaikannya penelitian ini.

3. Perancangan Aplikasi, Bertujuan untuk merancang sistem yang akan dibuat agar dapat di implementasikan dengan kebutuhan pengguna. Langkah-langkah yang dilakukan dalam perancangan aplikasi penjualan barang di Toko Citra Bahari Gypsum ini adalah Merancang database, Merancang Antarmuka, Mengembangkan Antarmuka.

4. Implementasi Sistem dan Evaluasi, merupakan suatu proses menterjemah dokumen hasil desain menjadi baris-baris perintah bahasa pemograman komputer. Semakin baik hasil analisis desain yang dilakukan, maka proses pengkodean ini akan lebih mudah dilakukan.

5. Pengujian, Pengujian penting dilakukan untuk meninjau kualitas software dan juga peninjauan terakhir terhadap spesifikasi, desain dan pengkodean.

6. Mengambil Simpulan, pada tahap ini disimpulkan bahwa apakah aplikasi yang dibuat sudah dapat memenuhi kebutuhan untuk melakukan suatu proses pekerjaan yang berkaitan dengan sistem komputerisasi penjualan barang Toko Citra Bahari Gypsum. Dengan penggunaan sistem aplikasi penjualan barang yang baru diharapkan dapat menghasilkan informasi yang berkualitas serta dapat membantu dalam proses pengambilan keputusan.

\section{HASIL DAN PEMBAHASAN}

Proses Bisnis yang berjalan pada Toko Citra Bahari Gypsum dalam proses penjualan adalah sebagai berikut:

a. Proses penjualan barang pada Toko Citra Bahari Gypsum pada sistem yang sedang berjalan dilakukan secara manual belum terkomputerisasi. Dimulai dari Customer melakukan pemesanan barang pada bagian administrasi yang datanya akan dicatat untuk masuk ke dalam data penjualan dengan media buku sebagai penggunaanya.

b. Proses cek stok barang, pada proses ini Bagian Administrasi melakukan pengecekan jumlah stok barang pada Petugas Gudang untuk mengetahui jumlah pasokan barang yang tersedia maupun penambahan jumlah pasokan sehingga dapat dilakukan sebuah pencatatan secara rinci.

c. Proses pembayaran, pada proses ini Customer melakukan pembayaran kepada Administrasi, untuk selanjutnya barang dikirimkan ke Customer. 
d. Proses pembelian barang, Bagian Administrasi melakukan pemesanan barang kepada Supplier untuk penambahan stok barang atau membeli barang yang sudah habis terjual.

e. Pembuatan laporan penjualan, pembelian dan pengadaan barang dilakukan oleh Bagian Administrasi dan diserahkan kepada Pemilik Toko.

Analisis permasalahan yang dapat disimpulkan dari hasil penelitian yang di lakukan di Toko Citra Bahari Gypsum adalah Toko Citra Bahari Gypsum belum menggunakan Aplikasi Penjualan Berbasis Java dan database MySQL dalam proses pengelolaan data dan transaksi penjualannya, sehingga sering ditemukan masalah seperti pengelolaan data yang tidak akurat, data yang mudah rusak dan hilang, serta membutuhkan waktu yang relatif lebih lambat. Ada beberapa permasalahan yang dimiliki oleh pihak toko antara lain, proses pengelolaan data masih dilakukan secara manual, yaitu dengan memakai buku besar, kurangnya keamanan dalam penyimpanan data-data di Toko Citra Bahari Gypsum, pembuatan nota penjualan masih dilakukan secara manual yaitu dengan tulisan tangan.

Alternatif penyelesaian masalah yang peneliti usulkan dengan membuat sebuah aplikasi penjualan took citra bahari gypsum dengan menggunakan bahasa pemrogramman java dan penyimpanan data-data pada media database. Dengan adanya aplikasi ini diharapkan mampu memberikan kontribusi yang positif bagi kemajuan dalam pengolahan data-data penjualan. Proses pencarian data tidak lagi membutuhkan waktu yang lama karena data-data yang sudah tersimpan pada media database. Dengan usulan ini diharapkan pemasalah pada pengolahan data-data simpan pinjam koperasi dapat tertangani dengan cepat dan akurat

Berikut ini adalah Gambaran sistem yang diusulkan di Toko Citra Bahari Gypsum secara keseluruhan dalam diagram konteks dan ERD (Entity Relationship Diagram).

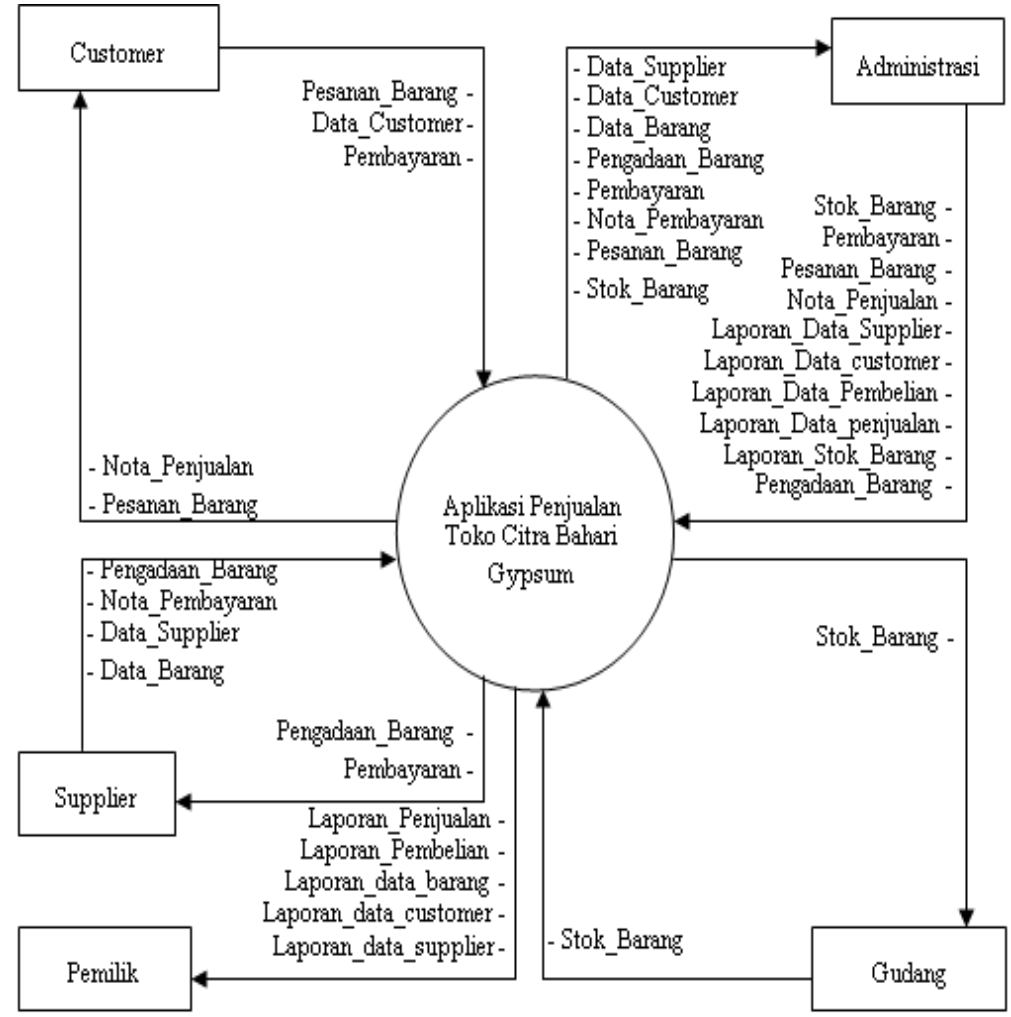

Gambar 1. Diagram Konteks 


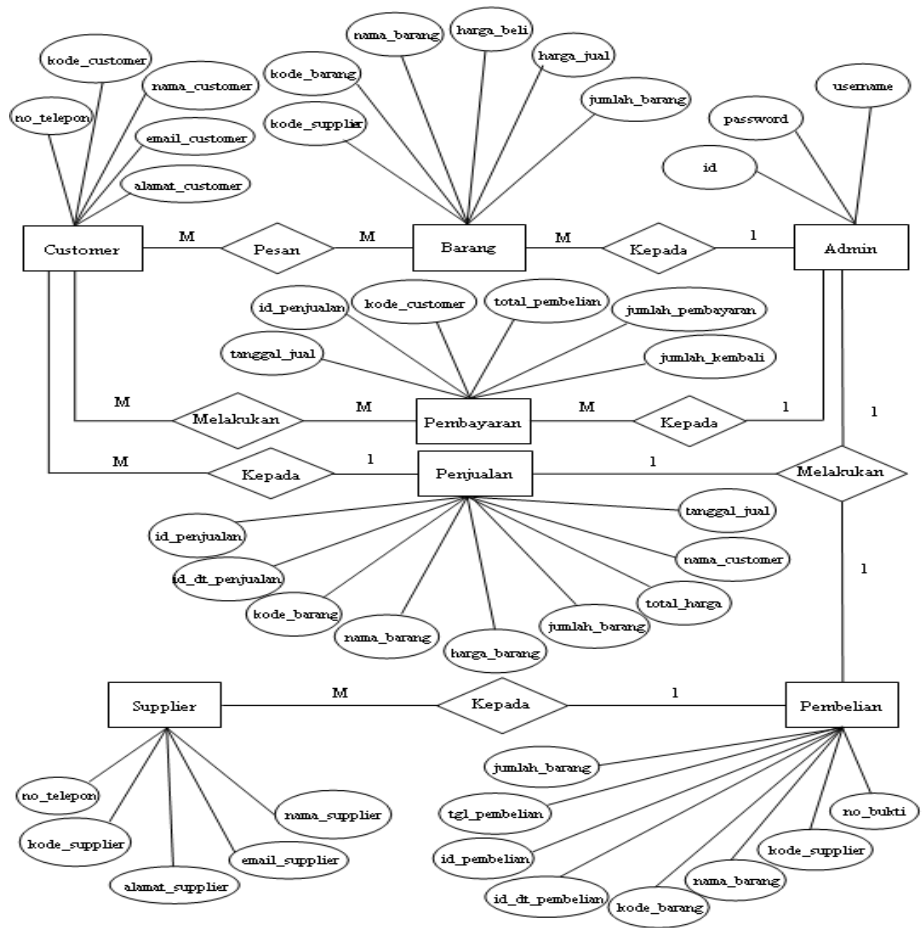

Gambar 2. Entity Relationship Diagram (ERD)

Proses selanjutnya peneliti membuat aplikasi ini dengan menggunakan java netbeans edisi 8.2 berbasis desktop dan menggunakan basisdata $M y S Q L$.

Dibawah ini adalah tampilan layar dari aplikasi penjualan Toko Citra Bahari Gypsum.

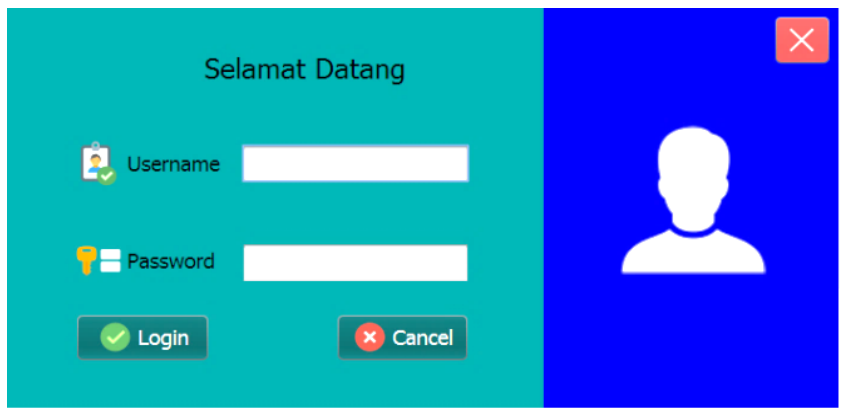

Gambar 3. Tampilan layar login

Tampilan login ini muncul di awal saat pengoperasian aplikasi. form login ini terdiri dari username dan password.

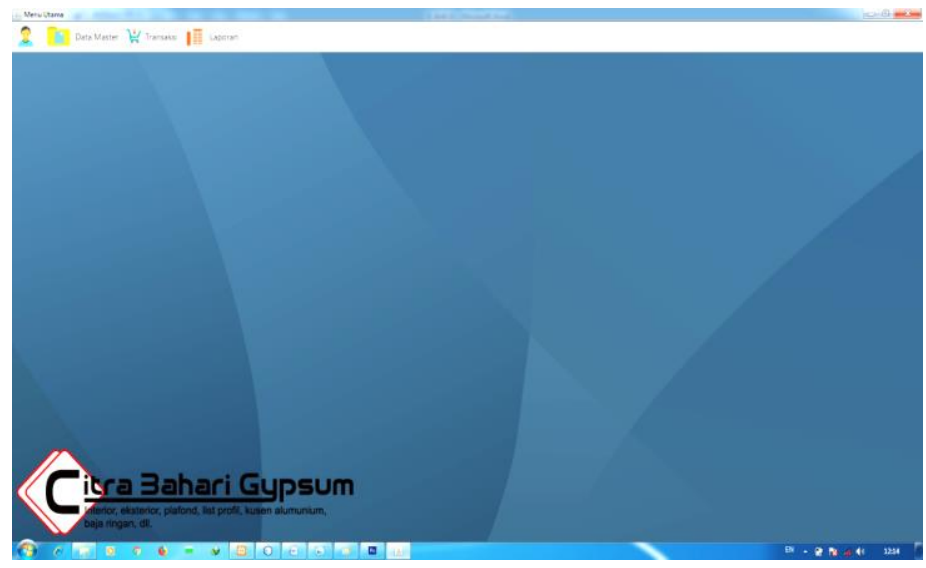

Gambar 4. Tampilan Layar Menu Utama 
Tampilan Menu pada Perancangan Aplikasi Penjualan Barang Toko Citra Bahari Gypsum. form menu terdiri dari 3 menu utama, yaitu Master (master data), Transaksi, dan Laporan.

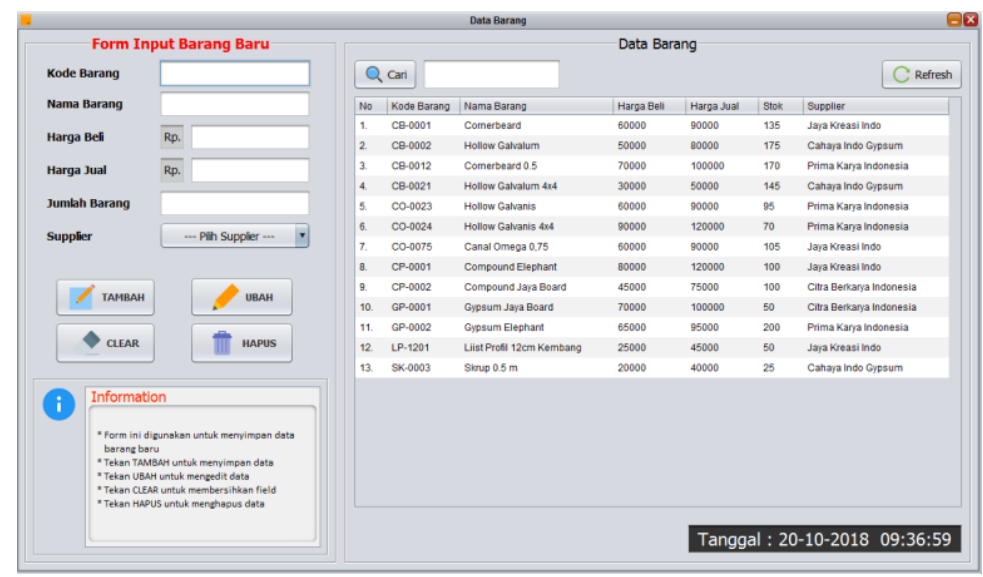

Gambar 5. Tampilan Form Data barang

Tampilan Form Data Barang terdiri dari inputan Kode Barang, Nama Barang, Harga Beli, Harga Jual, Jumlah Barang, Supplier. Klik Tambah untuk menyimpan data.

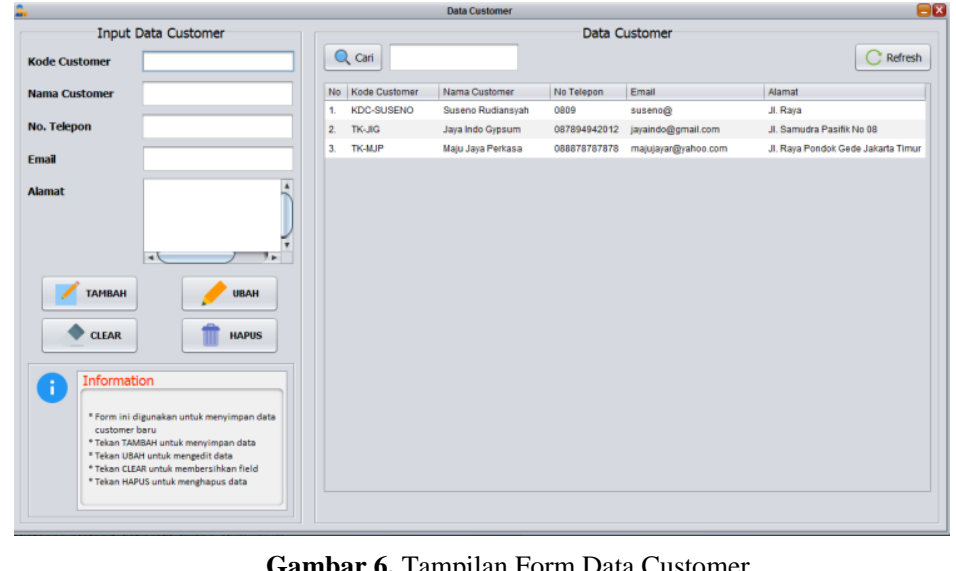

Tampilan Form Data Customer terdirir dari inputan Kode Customer, Nama Customer, No. Telepon, Email, Alamat. Klik Tambah untuk menyimpan data.

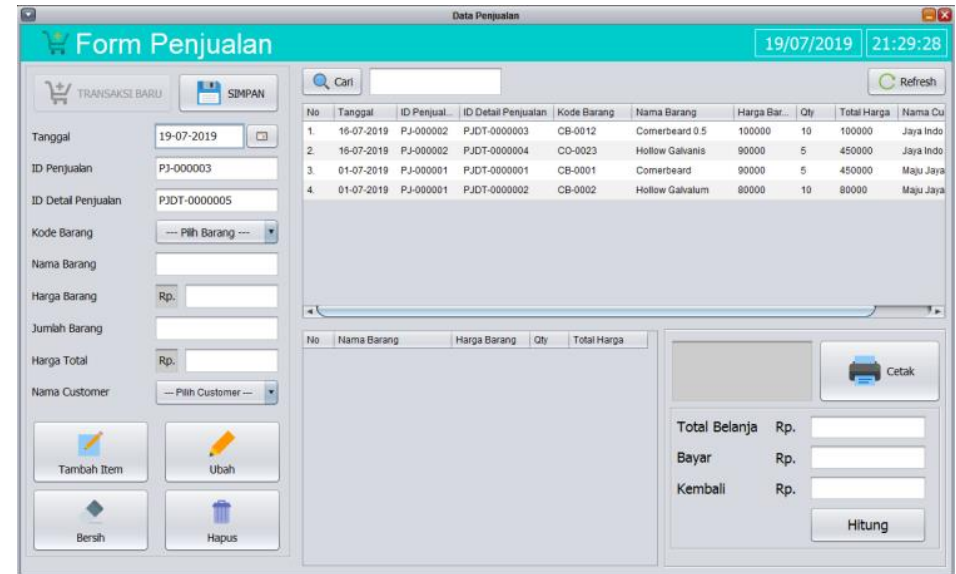

Gambar 7. Tampilan Form Transaksi Penjualan 
Tampilan Form Transaksi Penjualan Tanggal, ID Penjualan, ID Detail Penjualan, Kode Barang, Nama Barang, Harga Barang, Jumlah Barang, Harga Total, Nama Customer. Klik Tambah untuk menambah item, klik simpan menyimpan data.

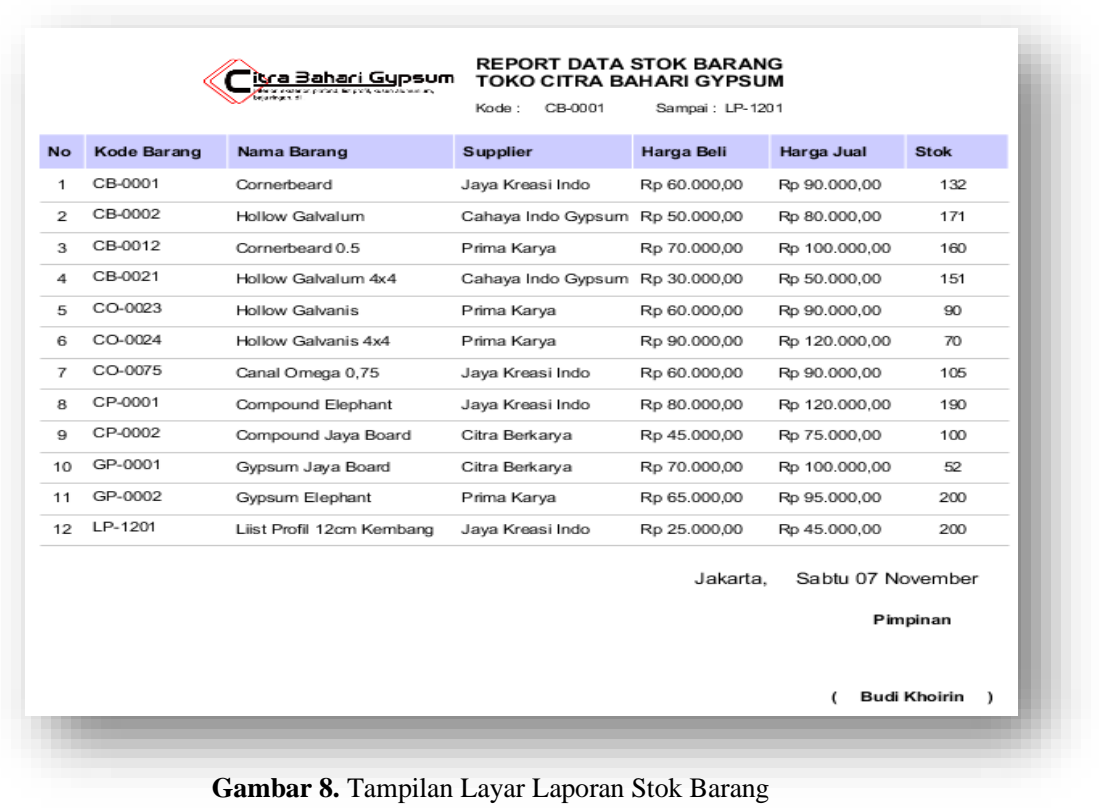

Gambar di atas adalah tampilan hasil laporan stok barang yang ditarik dari aplikasi stok barang melalui menu laporan stok barang.

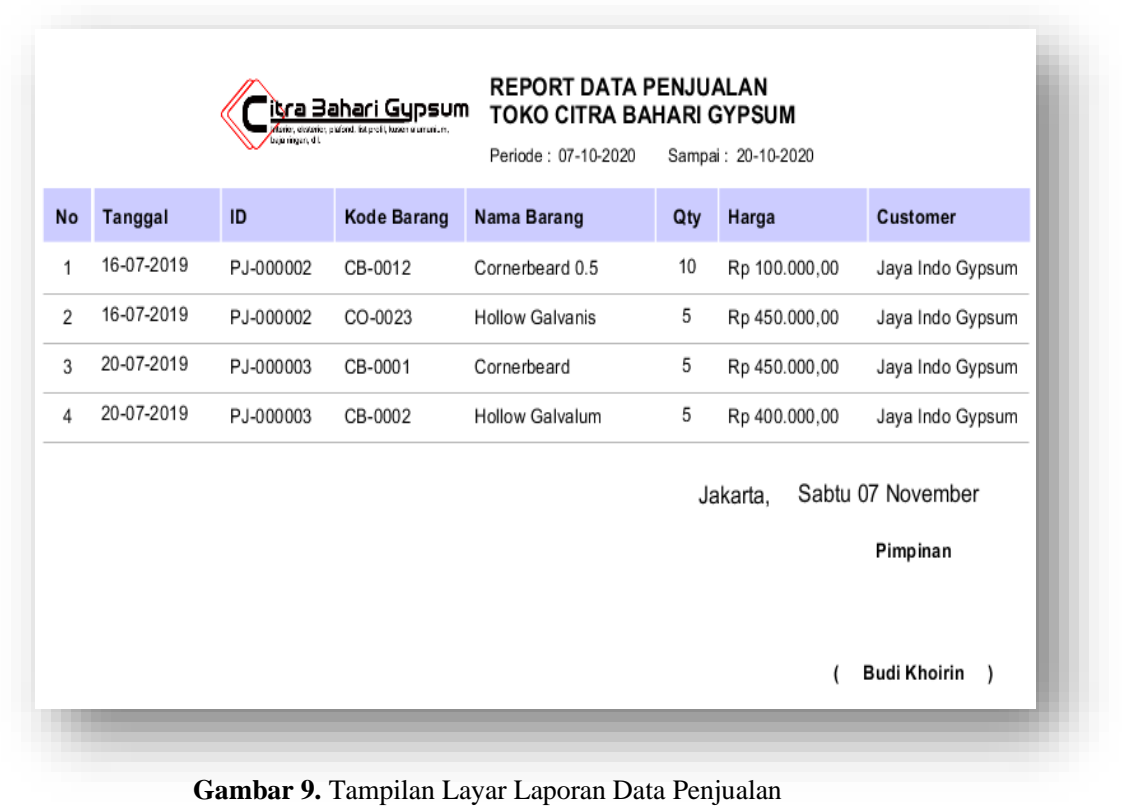

Gambar di atas adalah tampilan hasil laporan data penjualan yang ditarik dari aplikasi stok barang melalui menu laporan data penjualan. 


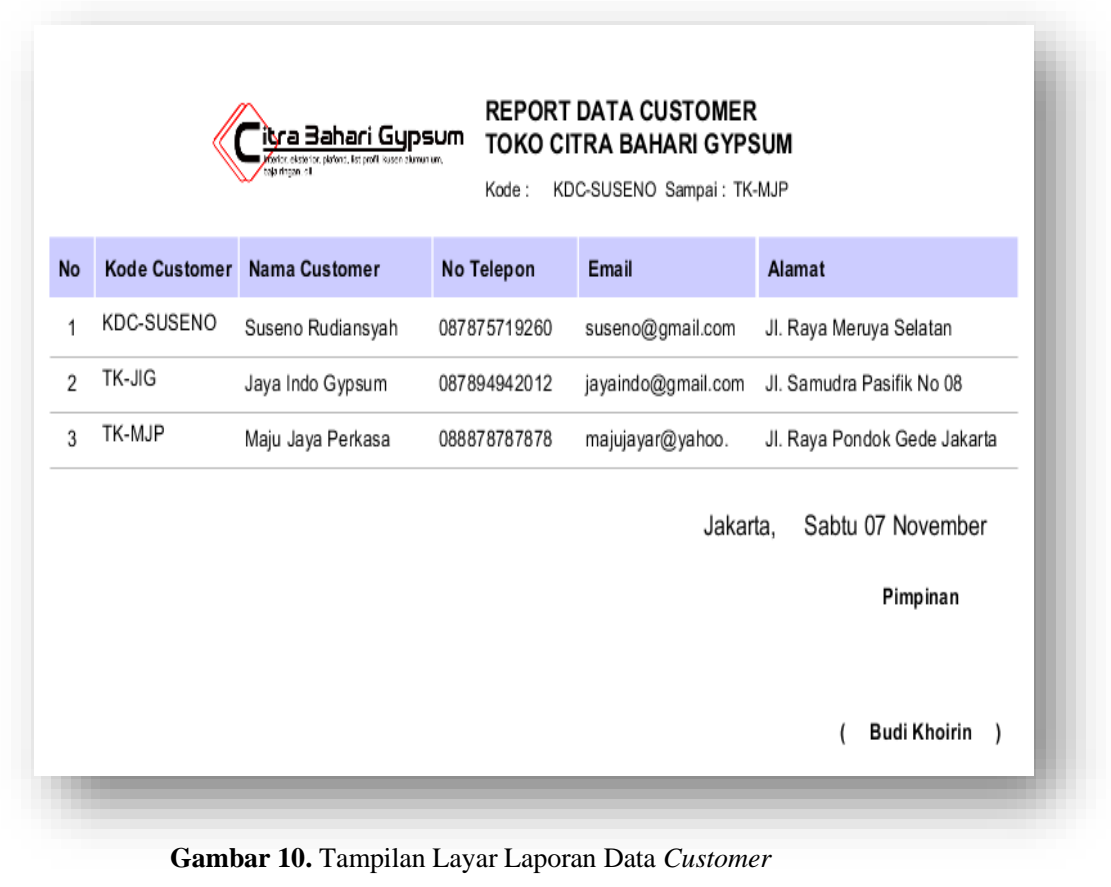

Gambar di atas adalah tampilan hasil laporan data customer yang ditarik dari aplikasi stok barang melalui menu laporan data customer.

\section{SIMPULAN}

Berdasarkan pembahasan dari penelitian ini , maka peneliti dapat mengambil kesimpulan yaitu: Perancangan sistem aplikasi yang dibangun dapat memberikan kemudahan pada Toko Citra Bahari Gypsum, memberikan keamanan pada data yang disimpan dan meningkatkan efektivitas dan efisiensi kinerja karyawan.

\section{DAFTAR PUSTAKA}

Adi, S. P. (2013). Perancangan Sistem Aplikasi Penjualan Toko Komputer Mascom Berbasis Dekstop. UMS.

Andi, K. (2014). Perancangan Sistem Informasi dan Aplikasinya. Graha Ilmu.

Ladjamudin, A. (2013). Analisis dan Desain Sistem Informasi. Graha Ilmu.

Nofriadi. (2015). Java Fundamental dengan Netbeans 8.0.2. Deepublish.

Pramana, H. W. (2012). Kunci Sukses Aplikasi Inventory berbasis Access 2003. In Jakarta: PT. Elex Media Komputindo. PT. Elex Media Komputindo.

Prasetyo, H. R. (2014). Perancangan Sistem Penjualan Berbasis Aplikasi Dekstop Pada CV. Canangsari Semarang. Journal of Information System (JOINS).

Subhan, M. (2012). Analisa Perancangan Sistem. Lentera Ilmu Cendekia.

Sugianto. (2013). Metode Penelitian Manajemen. Alfabeta.

Sulistyowati, L. (2010). Memahami Laporan Keuangan. PT. Elex Media Komputindo.

Tata, S. (2012). Analisis Sistem Informasi. Andi. 